\title{
Critical Reflections on Land Appropriation and Alternative Urbanization Trajectories in Periurban Vietnam
}

\begin{abstract}
Vietnam's land regime is currently undergoing a radical reshaping under policies of “urbanization and modernization.” Around large urban centres what could be called a “Third Land Reform” fosters massive land-takings for urban-industrial expansion. The forced appropriation of farmlands unsettles endogenous patterns of mixed-use development or "rural-urbanization" which have developed in these zones since the doi moi, and which are characterized by the combination of small-scale cottage industries with mixed employment, and commuting into the cities for jobs and trade. The Third Land Reform is driven by an official discourse of “modernization" that deems the endogenous rural-urbanization as backward (not modern). This discourse drives and defends an aggressive program of expropriation, to the benefit of corporate capital, to build “real” urban spaces. Foreign, planning scholars should not merely describe these processes, but point out the ideological justifications driving them, and the ways in which the things it rejects as non-viable may, in fact, have virtues that have been missed by the official view.
\end{abstract}

\section{Introduction}

Things have changed rapidly in Vietnam since the beginning of the so-called doi moi reforms. ${ }^{1}$ Since the late-1980s, the party-state has taken important policy steps with the aim of turning a poor agrarian society into an urban-based, industrial one, which will be on par with neighbouring Southeast Asian “tigers” by 2020 (Vietnam Communist Party 2006). These steps involved a loosening of the central state's controls over the allocation and use of public resources, and over people's movements and economic activities across the national territory. And it worked. By the 1990s Vietnam's urban transition, which had come to a near halt under the Soviet-style socio-economic system (1954-1986), was back in gear.

\footnotetext{
${ }^{1}$ These socioeconomic reforms gave market mechanisms a greater role in the domestic economy and opened it to foreign investments while preserving the political domination of the Vietnamese Communist Party.
} 
The progressive and selective transformation of the command-and-control economy should not, however, be mistaken for the full-fledged rolling back of the state. What we are rather witnessing on the edge of urban centres is a redefinition, under different parameters, of controls over land and people. This reaffirming of the state's power to govern territorially comes about through the active creation of what Peluso and Lund (2011) call "new frontiers of land controls:”

... sites where authorities, sovereignties, rights, and hegemonies of the recent past have been challenged by new enclosures, property regimes, and territorializations, producing new 'urban-agrarian-natured’ environments, comprised of new labour and production processes; new actors, subjects, and networks connecting them; and new legal and violent means of challenging previous land controls. (ibid.: 1)

In periurban Vietnam, this transformation of land controls is driven by new alliances between provincial level administrative officials (and occasionally central state officials) and a variety of corporate actors, who together, broker new governing practices and political-economic relationships. In an attempt to unpack this redefinition of the state's territorial powers, this paper takes a closer look at the massive, state-backed "land giveaway” which is currently unsettling territories and people already engaged in their own urban transition since the early 1980s. To act, morally or practically, on the politics of periurban governance in Vietnam, we must first get a better analytical grip on the mechanisms by which periurban households are excluded from access to the raw material of the urban transition in Vietnam, namely, publicly-owned, periurban croplands.

This paper takes a first step in this direction by exploring what Hall et al. (2011: 839) refer to as the exclusionary power of justification —-i.e., "the principled arguments about the ways in which land must be governed, allocated and used.” State agents, their business allies, and the mix of organizations and groups they employ, have invoked such arguments to establish their claims on periurban lands during the reforms. Building on a critical review of policy documents, international development agencies’ reports, secondary literature, and press clips, this paper explores how these justifications contributed to shape Vietnam's new frontiers of land controls over the last two decades. It 
looks at the various ways in which the state discourse and actions have entrenched the other 'powers of exclusion' identified by Hall et al. (2011) — that is, regulation, the market, and force-as politically and socially acceptable bases for pushing periurban households out of the lands that sustained the development of alternative, 'rural urbanization' processes since the agricultural decollectivization (1981-1993).

The remainder of this paper is organized as follows. Section I reviews major transformations of Vietnam's land regime ${ }^{2}$ throughout the $20^{\text {th }}$ century and outlines the main legislative changes that underpin what I term the "Third Land Reform." Section II discusses how the massive land-takings, made possible by the new legal framework, destructure the endogenous forms of periurban development, practiced around cities since the 1980s. Section III explores the official discourse on which state agents and their corporate partners rely to justify these land appropriations. I highlight the rooting of this discourse in an imagined urban modernity that devalues rural urbanization practices. The concluding section suggests that planning scholars need to advocate for an alternative and more equitable periurban future than that offered by the Third Land Reform. For this, scholars need not only a better understanding of the land appropriation phenomenon in Vietnam, but also of the ideological justifications driving it, and of the ways in which the things it rejects as non-viable may, in fact, have virtues that have been missed by the official view.

\section{The Third Land Reform}

For the last two decades or so, Vietnamese people have experienced increasing demand for urban land. This demand is felt most intensely around the large cities located in the Red River and Mekong delta regions, and at the periphery of other urban centres on the thin coastal plain linking these two regions. These are highly populated areas of compact cities and dense networks of villages, reaching over 10,000 persons per square kilometre in the Red River Delta region (DiGregorio et al. 2003). The pressure for new urban space in this zone is focused on croplands between these existing urban centres and rural settlements because, as will be seen below, new legislative arrangements have facilitated the appropriation and redevelopment of this public resource.

\footnotetext{
${ }^{2}$ The notion of "land regime" is understood here as the formal landownership system, the various formal institutions and the state organs that shape its geography and development.
} 
The allocation, use, and conversion of agricultural areas is the responsibility of the state, which according to the national constitution "manages” all land in Vietnam in the name of "the entire people" (2013 Constitution, art. 19). State agents at the central and local levels play a pivotal role in the periurbanization process, by arbitrating the fierce competition for this resource which developed during the 1990s, and which has since brought periurban villagers into close contact and competition with new suburban households, the owners of small rural industries, state-owned enterprises, domestic speculators, and foreign capital venture funds.

There have been important legislative and administrative changes over the course of the last two decades to regulate this contest. These included the passing of the first Law on Land in 1988, followed by three major revisions of this foundational legal document (in 1993, 2003 and 2013), and by the adoption of a flurry of decrees and administrative decisions aimed at clarifying land control rules. ${ }^{3}$

Official discourse has attempted to depoliticize these changes by introducing them as “adjustments" to the socialist land regime or as "technical solutions" to "technical problems." This is reflected in the language used in policy documents published since the early 1980s. Instead of using the politically-loaded expression "reform” (cải ca'ch), coined during the socialist revolution, official texts prefer to talk about policy “improvements” (cải thiện chính sách) and of "revisions of legislation” (sủa luật) within a wider “renovation” (đổi móri) of the country’s land administration system.

Notwithstanding this official language, the institutional transformations that have taken place since the early 2000s cumulatively amount to a radical shift in resource allocation rules, a profound enough transformation to be called the "Third Land Reform.” The recent evolution of the land administration framework is, in effect, reversing the movement of the two previous, postcolonial land reforms experienced by Vietnam during the $20^{\text {th }}$ century.

\footnotetext{
${ }^{3}$ For detailed reviews and discussions of these legislative changes, see Kerkvliet 2006, Scott 2009, and Mellac et al. 2010.
} 
In the year following the country's Independence, a first reform (1953-1956) redistributed agricultural lands to tenants and landless workers in Northern Vietnam. Inspired by Marxist-Leninist ideals, it then compelled peasants to pool their land and means of production into state-owned farming cooperatives. Following national reunification (1975), the party-state sought to impose collectivized farming in the south. This proved to be an economically disastrous initiative and it led to the abandonment of collective farming arrangements across the country (Kerkvliet 2005).

Although not formally referred to as a "land reform," the collapse of collectivized agriculture in the late 1970s triggered a policy revision process which was perhaps as radical as the first Soviet-inspired reform implemented two decades earlier. Between 1988 and 1993, the state progressively redistributed agricultural land (or land use rights) to rural households for private use. In contrast to the collectivist ideal of the first land reform, the state then adopted what might be called a "productivist" approach. New policies first individualized access to land. Later, they clarified and expanded property rights, and made tenure more secure for land use-right holders with the aim of boosting production and incentivizing long-term private investment. As widely acknowledged across the literature, the return to household-based farming stands behind the impressive record of poverty reduction achieved by Vietnam during the early years of the doi moi (e.g. Scott 2009; Pincus 2012; Wells-Dang 2013).

Despite their very different ideological bases, the two major transformations of the Vietnamese land regime which I have just outlined had strong, pro-poor orientations. Both sought to even out access to agricultural land (or its produce) across the rural population. Even policies adopted during the second more market-oriented reform of the late 1980s and early 1990s included provisions to maximize the equitable distribution of land among farming households. For instance, the 1993 Land Law prescribed periodic redistributions of agricultural lands at the local level to ensure land use equality (art. 33.1), and imposed a ceiling on the amount of land that each household can possess (art. 70).

By contrast, what I refer to as the Third Land Reform facilitates the dispossession of farming households from their land through the enclosure of great expanses of 
agricultural land at the edge of cities, and the transfer of this public asset to corporate actors (public, private, domestic and foreign) for redevelopment into new urban and industrial uses. Quoting a former Vice-Minister of Natural Resources and Environment (MONRE), Wells-Dang (2013: 5) rightfully concludes that this has led to a situation in which policy has become biased in favour of urban-industrial expansion and against agriculture, leading to unequal development and social problems (see also Le Duc Thinh et al. 2009).

I have discussed elsewhere the institutional evolution that led to the Third Land Reform (see Labbé and Musil 2013; Labbé 2013: chap. 4). To summarize, four broad regulatory changes have come together during the years 2000s to set this phenomenon in motion.

- First is a loosening of the conditions under which the state can revoke land-use rights and reassign them to new users. Since 2007, compulsory land acquisition can be carried out not only for national security and public interest purposes, as prescribed by the 2003 Law on Land, but also for any project "for important economic development, for residential areas, or for economic development in urban areas and rural residential areas” (Decree 84/2007/ND-CP, art. 34).

- Second is the adoption of a land valuation mechanism aimed at facilitating land redevelopment by maintaining croplands well below market values (Law on Land 1993). Since all land in Vietnam is publicly owned, it can only be lawfully acquired and allocated by the state. Compensation for the loss of land-use paid to the original land user is similarly determined by a state-stipulated price-chart issued annually. In a recent report, the World Bank (2011: 5) found these stateprescribed rates for lands to be 30-70 per cent below their estimated market values. While this artificial devaluation of land is theoretically meant to facilitate the realization of the state's urbanization and industrialization plans (Le Xuan Ba, 2006), it has also created a cheap reserve of developable land at the edge of cities that corporate actors have been keen to exploit (Labbé and Musil 2013).

- Third is the decentralization of land-use controls and expropriation powers. Throughout the 1990s, the central government strictly controlled the approval of 
investment projects and the conversion of even small areas of agricultural land. Any land use change had to be approved by the Ministry of Natural Resources and Environment (Law on Land 1993, art. 23). However, in 2006 and 2009, two new laws decentralized these powers, by first allowing provincial governments to approve investment projects on their territory (Decree 108/2006/ND-CP), and then by allowing them to expropriate and convert agricultural areas for projects of up to 200 hectares (Decree 12/2009/ND-CP). ${ }^{4}$

- Fourth, and finally, is the new Law on the State Budget (2002), which allows provincial and district governments to expand their autonomous budgets by retaining the revenue of certain taxes and fees previously transferred to the central government. This includes taxes and fees levied on new land-users (including investors) when land is converted and transacted. This incentivizes provinces to boost land market activities on their territories. For instance, in 2010, nearly $30 \%$ of Ho Chi Minh City's provincial budget came from land-related taxes and fees (Tran Anh Tuan, 2013).

Echoing changes observed in other parts of developing Asia (see for instance, Levien 2012 on India and Hsing 2010 on China), stronger eminent domain powers and more decentralized controls over land disposition incentivizes public authorities and developers to exploit the rent gap between agricultural lands, acquired from small-holders at cheap nominal compensation rates, which can then be redeveloped as higher-value (residential, commercial, industrial) land. Recent publications by academics and by international agencies concur to show that the commercialization of public land assets, while done in the name of the "public interest," brings most benefits to powerful domestic interests operating at the frontier between the state and the private business sector, while hitting rural populations hardest (Albrecht et al. 2010; Embassy of Denmark et al. 2011; DiGregorio 2011; Labbé and Musil 2013; Le Duc Thinh et al. 2009; Nguyen Quang Phuc et al. 2014; Wells-Dang 2013).

\footnotetext{
${ }^{4}$ Approval from the central government is only required for projects with investments of more than 80 million USD and those in 'sensitive' sectors such as national defense and telecommunication.
} 


\section{Alternative Periurban Futures Unsettled}

There are plenty of reasons for researchers, activists, and policymakers to be concerned with the impacts of the Third Land Reform on periurban territories and people. A group of three international development agencies have recently reported that between 2000 and 2009, nearly one million hectares (one sixth of Vietnam's total arable land area) was turned to non-agricultural uses including public infrastructure and private projects such as industrial zones, residential estates, golf courses, and tourist resorts (Embassy of Denmark et al. 2011: ix). From 2000 to 2005 alone, compulsory land appropriations throughout the country are estimated to have forced approximately two million households off their land (Albrecht et al. 2010: 15). These massive land-takings disrupt, at great human cost, pre-existing urbanization dynamics around large urban centres.

Since the 1980s (and in some cases even before that), vast territories and millions of people surrounding Hanoi, Ho Chi Minh City, Danang, Haiphong and other large cities in Vietnam have been engaged in the creation of desakota or extended metropolitan regions such as those discussed by Terry McGee and others (e.g. Ginsburg et al. 1991). Through this process, and in contrast to the conventional city-based urbanization process dominated by rural-urban migration, rural settlements around Vietnam's main urban centres have progressively transformed into urban or quasi-urban places with limited geographical relocation of their populations. Rather, a majority of periurban households have expanded the role of non-agricultural work, adopted urban settlement patterns and housing forms, along with what might be termed 'urban' ways of life, without leaving their place of residence or, at least, without leaving it permanently (DiGregorio et al. 2003; Taylor 2005; Hoang Xuan Thanh et al. 2005, 2008).

During the 1980s and 1990s this process absorbed the labour of millions of underemployed and low-skilled peasants freed from agricultural work by the breaking down of agricultural cooperatives. By keeping periurban people in place, the in situ urbanization and industrialization alleviated the pressure created by rural-to-urban migration on municipal administrations, such as those of Hanoi and Ho Chi Minh City, which have long struggled to provide their populations with decent housing, services, and jobs. One can even surmise that the diversification of employment both on and off the farm was more effective in keeping rural migrants from flooding urban areas than the 
state's “defensive” policy measures that deny rural-urban migrants the household registration permits ( $h \hat{~}$ khẩu) they need to access public services in the cities (e.g. . schools, hospitals, marriage registration, birth and death certificates, etc.).

We could call the change process observed around major cities "rural urbanization," and it is largely endogenous. This process is fuelled by the entrepreneurial spirit of households and communities, regulated by local norms, and shaped by the creative exploitation of local resources, traditional know-how, modern technologies, and social relations. This is also a heterogeneous phenomenon, with considerable variation from one community or region to the next. Examples of this diversity include the well-researched case of farming households in the Mekong Delta having shifted from low value-added paddy to commercial aquaculture (e.g. shrimp farming) and high-value commodity crops (e.g. fruits, cashew nuts). It also includes the impressive growth of the so-called 'craft villages' in the Red River Delta region. Currently, about 1,000 such villages in the Red River Delta produce daily goods for the domestic market and for export. As noted by Fanchette (2012: 260), craft villages enjoy incomes several times greater than those of agricultural villages and have able to improve their living conditions throughout the last decades (Hoang Xuan Thanh et al. 2005, 2008; DiGregorio 2003).

Less celebrated by policy-makers, but not less important in terms of labour-absorption and livelihood diversification, are the services set up by households to organize consumption and production around cities. This includes the strings of cheap restaurants established between population centres to service travellers, the tens of thousands of cafes set up along lowland transportation corridors, and the myriad of open-air markets and small goods stalls found in even the smallest periurban settlement. Periurban people also diversified their livelihoods into what Taylor (2005: 162) has termed "the economy of mobility," a phrase he uses to refer to all sorts of mobile and mobility related work such as petrol stations, car, bus and truck fleets, motorcycle dealerships, fertilizer distributors, people who make a business from moving earth around, and the providers of mobile work crews.

A common trait among this diversified change process is the long-standing preference of periurban and, in fact, most rural households for the establishment and maintenance of 
pluri-active livelihood strategies that variously mix subsistence or commercial agriculture with petty trading and small services, along with sending members of the household out to engage in wage-work, be that in urban centres, large industries or craft villages (e.g. Scott 2009; Nguyen Van Suu 2009; Fanchette 2012). In crafting their own post-agrarian future, these households continue to value their access to farmland. Illustrating this, since the legalizing of land market transactions by the 1993 Law on Land, only a small number of households have chosen to sell their agricultural land (or, rather, to transfer their userights) (Scott 2009; Deinenger and Jin 2008). The reluctance of farmers to part with this natural capital is more than a cultural or symbolic attachment. It also goes beyond needs to exploit this resource for subsistence or commercial farming.

Rather, continued access to farmland underpins a complex local economic system while also providing leverage to households in the transition to more urban lives. To give only a few examples, the operators of cottage industries use their agricultural land use-rights as collateral in the non-official credit system on which most informal businesses depend in Vietnam. Other households rent their farmlands to extended family members or neighbours while developing non-agricultural activities. Others still, use it to provide a productive occupation for their less qualified or older members, or else rely on subsistence farming as a temporary livelihood "fallback" during harsh economic periods.

In these various ways, the continued access to farmlands tempers the pace of the urban transition by allowing periurban households to move back and forth between 'rural' and 'urban-industrial' occupations. The ongoing access to agricultural livelihoods helps to control, if only minimally, economic change, and is a safeguard against an increasingly volatile economic and natural environment.

By cutting households' access to farmland, The Third Land Reform unsettles these complex livelihood and economic strategies. Periurban people are dispossessed of their agricultural lands through state-backed land expropriation processes without, in most cases, being forced to leave their homes. This results in a displacement "at home" as the new industrial, residential or recreational zones built on farmland only provide work to a fraction of the labour force that these lands previously sustained (Nguyen Van Suu 2009; Le Duc Thinh et al. 2009; Nguyen Quang Phuc 2014). The most vulnerable segments of 
this population (especially older, less educated, and less mobile populations) are pushed into what Tania Li (2010: 66) calls "the truncated trajectory of agrarian transition [...] in which there is no pathway from country to city, agriculture to industry, or even a clear pathway to stable plantation work that pays a living wage.”

\section{Justification Matters}

What principles allow the Third Land Reform in Vietnam to roll over the pre-existing, periurban development process? How, to use the words of Henri Lefebvre (1991: 49), does "the dominant form of space, that of the centre of wealth and power, endeavour to mould spaces it dominates (i.e. peripheral spaces) [...] and to reduce the obstacles and resistance it encounters there”? Part of the answer to this question lies in the pervasive discourse about an imagined urban modernity deployed by central and provincial officials and their corporate partners since the 1990s.

As other writers have noted, central governments in the Asian transition countries have crafted a connection between urbanization and the overarching agenda of economic development (Woodside 1998; Hsing 2010). State seizures of agricultural land in Vietnam are supported by similar discourses about the need to relieve urban housing shortages, to upgrade and expand infrastructure networks (especially roads), and to make space for an urban-industrial economy which, at least in official statements, will allow Vietnam to claim the much sought-after title of “industrialized nation” by 2020 (DiGregorio 2011; Taylor 2005).

A centrally important but less discussed aspect of official discourse around urbanization in Vietnam frames the issue as a clash between progress and peasants, between modernity and traditional lands. It is this view of a fundamental clash that serves to justify the new frontiers of land controls, and especially the massive state-backed land expropriations, characteristic of the Third Land Reform. By negating the value and diversity of the localized rural urbanization trajectories discussed in the previous section, this wrongheaded ideology of modernity supports (or else, justifies after the fact) the adoption of land-use rules, allocation mechanisms, and other land controls which ignore the central role played by periurban agricultural lands in the functioning of local socio-economic systems. 
At a symbolic level what I have described as rural urbanization is portrayed in official discourse as an improper form of development, out of place in a nation that wishes to project a modern image. Rather than a wholesale dismissal of rurality, the imagined, 'traditional village' is still treated with some deference in official discourse-it is, after all, supposedly the cradle of the Vietnamese civilization. The problem instead is the contemporary 'urbanized village’ in which economic activities are in large part 'undisciplined' by central plans and which, therefore combines the disorder (thiếu trật tụ) of the urban world with the 'backwardness' (lạc hậu) of the rural one. In planning documents and in official addresses the largely informal functioning of these places is presented as thwarting the construction of the orderly urban landscape of high-tech industrial zones, modern residential areas, and modern infrastructure (DiGregorio 2011; Labbé 2013: chap 4).

The exclusionary power of the Third Land Reform's justification is also based on the oversimplification of the role of agricultural lands in the endogenous periurbanization process. Echoing modern state governmentality practices analysed by James C. Scott (1998), legal texts and land administration instruments in Vietnam ignore croplands' multifunctional role in sustaining the development of flexible, post-agrarian economies on the edge of cities. Reduced to its basic crop production function, this asset is deemed to be of little value in the construction of an urban-industrial economy and society. After all, with the exception of the Mekong Delta region, agricultural land in periurban Vietnam is mainly exploited for subsistence purpose and therefore contributes only marginally, if at all, to the national gross domestic product and other standard measure of economic progress used by state economists and international financial institutions.

As emphasized by Le Duc Thinh et al. (2009) farmlands are treated in legal texts as an 'under-used' or low-yielding resource whose full value, and hence, contribution to the national economic development process, can really only be unlocked by redevelopment into new and more profitable functions. The harm done to the dispossessed is thus diminished, by suggesting it was of little good anyway. As a further consequence of this reasoning there is little concerned paid to making sure that the lost livelihoods of the dispossessed are replaced with something as good or better. But this discourse of little 
harm is betrayed by the reality; the areas acquired in periurban Vietnam support a large number of people with a variety activities not only in the form of paddy and vegetable cultivation, but also in horticulture and fish farming, not to speak of non-farm activities in the trade and service sectors.

\section{Conclusion: The Way Forward}

What are we, urban and planning scholars, to do in the face of what the journalist Tran Dinh Thanh Lam (2006) calls the 'Great Vietnam Land Grab’? How are we to address the politics of the Third Land Reform, in solidarity with the transforming agrarian communities currently targeted by the urban bulldozer?

A door might be open in this period of rising dissent and legislative revisions in Vietnam, for both local and foreign planning scholars to contribute to the debate about periurban land administration, and the governance of the urbanization process. The last few years have seen a series of high-profile disputes, corruption, and embezzlement cases related to periurban land management (for short reviews, see Brown 2012; Marr 2012). These conflicts emerged as the real estate market in Vietnam suffered from one of its worst slowdowns, and as legislators were revising the National Constitution, and the Law on Land, the two most important legal texts governing the land resource.

So far, this has been a many-sided conversation involving, among others, peasants targeted by expropriations, representatives of the state at various administrative levels, local activists and intellectuals, members of the Vietnamese diaspora, and foreign journalists whose viewpoints are exchanged through the mix of formal and informal channels which make a semblance of public debates possible in socialist Asia (Kim 2011). Despite its relative lack of focus, new ideas have started to emerge through this public dialogue, along with demands to rethink the property regime and regional planning models so as to make more space for periurban settlements, and the specific needs of their people (Gillespie 2012; Wells-Dang 2013).

I have focused here on the justifications behind the Third Land Reform, the discursive construction of a good urban modernity that should replace a supposedly backward rurality, because I believe that our work, as planning scholars, by illuminating the 
processes that are driving this transformation, can contribute to this public discussion and 'brainstorming' about the way forward. By opposing the multiple advantages of the vernacular modernization going on around cities to the imagined virtues of the current state-led urbanization by dispossession, planning research can further support the construction of a counter-discourse about the future of urbanization in Vietnam. As seen in this paper, these advantages include a high rural labour absorption capacity leading to balanced spatial development between urban and rural areas, and the development of economic activities founded on local resources and knowledge, which have proved both resilient and adaptable during periods of great change and volatility.

Rather than dispossessing periurban places and people from the basic assets on which they have thrived for more than two decades, the onus should be on the centre to learn, adapt, and adjust to what is going on around cities. This should however be done with a degree of critical objectivity, recognizing, for instance, that just because this kind of development is endogenously driven, does not mean that it is without problems or that it does not require state control. To give only one example, research on periurban craft villages in the Red River Delta has highlighted important public health and environmental problems (Dang et al. 2013). If the endogenous model of industrial development is to make a sustainable contribution to the urbanization process such issues need to be addressed.

Finally, we also might prospectively explore whether it is possible to accommodate, on the same territory, a variety of different kinds of activities, varying from those of real estate markets to the everyday practices of periurban populations, which offer heterogeneous pathways to the imagined good that is the "urban.” These are not small tasks, but they are ones which resourceful planning imagination can, I believe, productively tackle.

\section{Acknowledgments}

The author would like to thank the authors of this special issue, Andrew Wells-Dang, and John McKay for helpful comments on earlier drafts. The paper is better for their contributions, but any shortcomings remain the author's own. 


\section{References}

Albrecht, D et al. (2010) Les acteurs publics locaux au coeur du développement urbain vietnamien. Focales, Agence française de développement.

Brown, D (2012) Vietnam's Contentious Land Law, Asia Sentinel, 1 February 2012, http://www.asiasentinel.com/index.php?option=com_content\&task=view\&id=418 4\&Itemid=213 [accessed 15 February 2013].

Deininger, K and Jin, S (2008) Land Sales and Rental Markets in Transition: Evidence from Rural Vietnam, Oxford Bulletin of Economics and Statistics 70 (1), 67-101.

DiGregorio, M et al. (2003) The Invisible Urban Transition. Paper presented at the 7th International Congress of Asian Planning Schools Association, Hanoi, 12-14 September.

DiGregorio, M (2011) Into the land rush: facing the urban transition in Hanoi's western suburbs, Intl Dev Plann Rev. 33 (3), 293-319.

Embassy of Denmark, et al. (2001) Recognizing and reducing corruption risks in land management in Vietnam, Hanoi, National Publishing House.

Fanchette, S (2012) The Craft Villages of the Red River Delta (Vietnam): Periodization, Spatialization, Specializations. in Arfini F et al. (Eds.) Local Agri-food Systems in a Global World: Market, Social and Environmental Challenges. Newcastle upon Tyne, Cambridge Scholars, pp. 260-78.

Ginsburg, N et al. (Eds) (1991) The Extended Metropolis: Settlement Transition in Asia, Honolulu, University of Hawai'i Press.

Gillespie, J (2012) Vietnam: Will Property Rights Solve Land Disputes? Inside Story, 22 May 2012, http://www.eastasiaforum.org/2012/05/22/vietnam-will-propertyrights-solve-land-disputes/ [accessed 16 December 2013].

Hall, D et al. (2011) Powers of Exclusion: Land Dilemmas in Southeast Asia, Honolulu, University of Hawai'i Press

Hoang Xuan Thanh et al. (2005) Livelihood Diversification and Rural-Urban Linkages in Vietnam's Red River Delta, Working Paper on Rural-Urban Interactions and Livelihood Strategies No. 11, London, International Institute for Environnent and Development.

Hoang Xuan Thanh et al. (2008) Urbanization and rural development in Vietnam's Mekong Delta, Working Paper on Rural-Urban Interactions and Livelihood Strategies No. 14, London, International Institute for Environment and Development.

Hsing, Y.-t (2010) The Great Urban Transformation: Politics of Land and Property in China, Oxford, Oxford University Press.

Kerkvliet, B (2005) The Power of Everyday Politics: How Vietnamese Peasants Transformed National Policy, Ithaca, Cornell University Press.

Kerkvliet, B (2006) Agricultural Land in Vietnam: Markets Tempered by Family, Community and Socialist Practices, Journal of Agrarian Change 6 (3), 285-305.

Kim, A M (2011) Talking Back: The Role of Narrative in Vietnam's Recent Land Compensation Changes, Urb. Stud. 48 (3), 493-508.

Labbé, D (2013) Land Politics and Livelihood on the Margins of Hanoi (1920-2010), Vancouver, UBC Press. 
Labbé, D and Musil C (2013) Periurban Land Redevelopment in Vietnam under Market Socialism, Urb. Stud. Published online before print, 11 July 2013 DOI: 10.1177/0042098013495574.

Le Duc Thinh et al. (2009) The Crafting of Land Tenure Policies, Hanoi, Institute of Policy and Strategy for Agricultural and Rural Development.

Le Xuan Ba (Ed.) (2006) Policies on Attracting Investment into Real Estate Market in Vietnam, Hanoi, Publisher of National Politics.

Lefebvre, H (1991) The Production of Space, Oxford, Blackwell.

Levien, M (2012) The land question: special economic zones and the political economy of dispossession in India, J. Peasant Stud., 39 (3-4), 933-969.

Li, T M (2010) To Make Live of Let Die? Rural Dispossession and the Protection of Surplus Populations, Antipode 41 (1), 66-93.

Marr, D G (2012) Vietnam's High Profile Land Dispute. Inside Story, 23 March 2012. http://inside.org.au/vietnam-high-profile-land-dispute/ [accessed 15 March 2013].

Mellac, M et al. (2010) La réforme foncière au Vietnam, Hanoi, Agence Française de Développement and Ministère des Affaires Étrangères et Européennes.

Nguyen Quan Phuc et al. (2014) Agricultural Land for Urban Development: The Process of Land Conversion in Central Vietnam, Habitat Intl. 41, 1-7.

Nguyen Van Suu (2009) Agricultural land conversion and its effects on farmers in contemporary Vietnam, Focaal 54 (1), 106-113.

Peluso, N and Lund C (2011) New frontiers of land control: Introduction, J. Peasant Stud. 38 (4), 667-681.

Pincus, J (2012) Vietnam's Reforms: The Road to Market Leninism, London, Legatum Institute.

Scott, J C (1998) Seeing Like a State: How Certain Schemes to Improve the Human Condition Have Failed, New Haven, Yale University Press.

Scott, S (2009) Agrarian Transformations in Vietnam: Land Reform, Markets, and Poverty. in Spoor M (Ed.) The Political Economy of Rural Livelihoods in Transition Economies. Routledge, London, pp. 175-200.

Taylor, P (2005) Wealth in diversity. Proceedings from the Third High Level Roundtable Meeting on 20 Year Review of Doi Moi. Vietnam Academy of Social Sciences. Hanoi, pp. 135-68.

Tran Dinh Thanh Lam (2006) The Great Vietnam Land Grab, Asia Times Online, 10 August 2006. Retrieved from: http://www.atimes.com/atimes/Southeast_Asia/HH10Ae01.html.

Tran Anh Toan (2013) Local Administration: The Case of Ho Chi Minh City Budget Governance, Paper delivered at the conference Les villes émergentes en Asie du Sud-est, Ambassade de France au Laos, Vientiane (Laos), 26-28 November 2013.

Trung Dinh Dang et al. (2013) Living with Pollution: Juggling Environmental and Social Risk in Vietnam's Craft Villages, Critical Asian Studies 45 (4), 643-669.

Vietnam Communist Party (2006) Transactions of the $10^{\text {th }}$ Party Congress, Hanoi, National Political Publisher.

Wells-Dang, A (2013) Promoting Land Rights in Vietnam: A Multi-Sector Advocacy Coalition Approach. Paper delivered at The Annual World Bank Conference on Land and Poverty, Washington D.C., 8-11 April 2013. 
Woodside, A (1998) Exalting the Latecomer State: Intellectuals and the State During the Chinese and Vietnamese Reforms, China J. 40 (July), 9-36.

World Bank (2011) Recognizing and reducing corruption risks in land management in Vietnam, Hanoi, The National Political Publishing House. 